\title{
Polymorphism of growth hormone gene in the artificial insemination result of Madura cattle with Limousin semen as a reference for genetic selection
}

\author{
B. Utomo and E. Safitri* \\ Department of Reproduction Veteriner, Faculty of Veterinary Medicine, Universitas Airlangga, Surabaya, Indonesia \\ *Correspondence Author, ES: rma_fispro@yahoo.com/erma-s@fkh.unair.ac.id
}

(Received November 27, 2017; Accepted December 30, 2017)

\begin{abstract}
Research on genetic polymorphism of growth hormone $(\mathrm{GH})$ and receptor growth hormone $(\mathrm{rGH})$ has not been done in crossbred of Limousin cattle, so it is interesting to be examined. Blood samples were taken from 14 Madura calves were artificially inseminated with Limousin cement. DNA amplification is done by using Polymerase Chain Reaction (PCR) method, Restriction Fragment Length Polymorphism (RFLP) method to determine the genotype. DNA sequencing was done to determine nucleotide sequences of GH unit genes. The results showed that identification of GH and rGH gene polymorphisms was done by breaking DNA fragments from 432 and 298 bp in Madura and Limousin cattle (Madrasin) ie, L and V alleles have a frequency of 0.67 and 0.33 for the GH gene, respectively. This proves that the crossed-breeding of Madrasin have V allele that is not owned by the Madura cattle. While in the rGH gene, the A allele is 0.92 and the G allele is 0.08 , with the frequency of the A allele larger than the $\mathrm{G}$ allele. This research concluded: that $\mathrm{GH}$ and $\mathrm{rGH}$ undergo changes on polymorphisms in Madrasin cattle can be used as a basis for selection.
\end{abstract}

Keywords: Polymorphism, GH Gene, rGH Gene, Madrasin, PCR, RFLP, V alleles Available online at http://www.vetmedmosul.org/ijvs

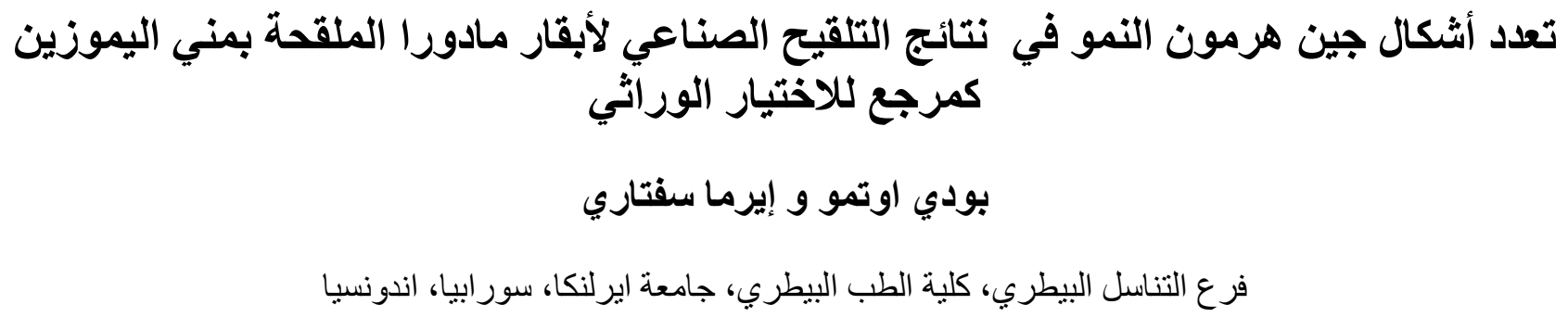

لم تجرأبحاث على تعدد الأشكال الوراثي لهرمون النمو (GH) وهرمون النمو المستقبلي (rGH) في الأبقار المهجنة من أبقار

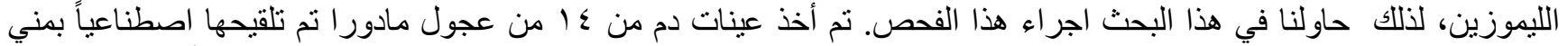
اليموزين. تم إجراء تضخيم الحمض النووي باستخدام طريقة تفاعل البوليميراز المتسلسل (PCR)، طريقة تعدد الأشكال (RFLP)

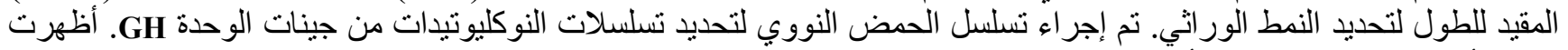

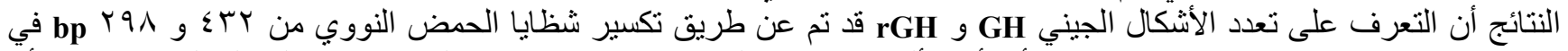

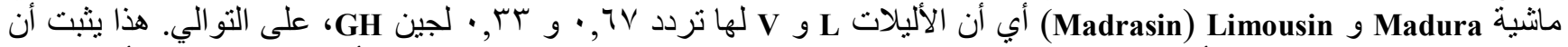

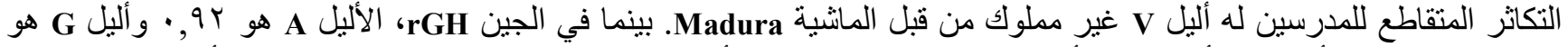

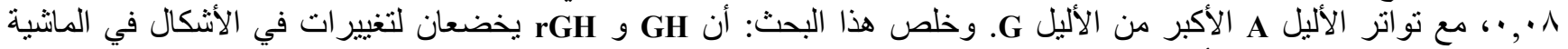
Madrasin 


\section{Introduction}

Madura cattle is one of Indonesia's germplasm wealth. Several laws enacted in an effort to maintain its purity and set out the main points of animal husbandry and animal health, in an effort to maintain the population, shape, colour of the skin, and improve the quality of Madura cattle production.

Madura cattle is one type of local Indonesian cattle that grow on the island of Madura and surrounding islands. Morphologically, Madura cattle have almost the same characteristics as Balinese cattle except for their smaller body size and horns. The skin colour of male and female Madura cattle is browner than Bali cattle, lower legs to knees (1). In addition, Madura cattle are more resistant to hot weather, efficient to food, have good meat quality, and more resistant to parasites (2).

Madura cattle become a local breed of beef cattle that is formed as a result of natural isolation and environmental influences, so it has a uniformity characteristic that stands out among other local beef breeds in Indonesia. With the contribution of genetic characteristics of zebu cattle such as tolerance to stress due to climate, resistance to tick attack, strict natural, and environmental selection a long time, Madura cattle become a cattle breed that has a very high adaptability to the environment. In addition, Madura cattle have a good response to the improvement of feed and resistance to feed with high crude fiber content (3).

The exploitation of Madurese cattle through an increasingly widespread crossing with exotic cattle will have the effect of changing phenotypic and genetic traits. Crosses are done by breeders to obtain superior performance especially for weight growth and reproductive power.

Therefore, genetic studies of Madura cattle that have been crossed with Limousin breed become interesting to do in order to see the calves produced have a good quality in terms of body growth and reproduction. Furthermore, the results of the genetic selection will be used as a reference for obtaining superior calves from Madura cattle that are inseminated with limousin cement.

Advances in the field of molecular biology provide new opportunities in an attempt to detect the occurrence of genetic variation (polymorphism) as a basis for improving genetic quality in farms. Potential molecular techniques used to detect variations include Restriction Fragment Length Polymorphism (RFLP), Random Amplified Polymorphism DNA (RAPD), Double Strand Conformation Polymorphism (DSCP), and Marker-Assisted Selection (MAS). With effective and accurate technology through the use of diagnostics based on deoxyribonucleic acid (DNA), it will greatly assist cattle crossing programs. Provision of genetic maps through recombinant DNA methods can assist cattle crossing programs through obtained molecular data, which regulate the properties of production (4).

Gene products in the form of hormones will affect the regulatory process of metabolism and appearance of (bioregulators) livestock morphology. Genetic variation (polymorphism) in gene loci especially that encodes hormone is very important because it determines the genetic character of a population that can assist in improving the genetic quality (5).

Growth hormone is one of the gene products which has a major effect on the growth, lactation and development of mammary glands in cattle (6). Polymorphisms in genes that encode and regulate growth hormone are very potential as genetic markers for phenotypic properties with high economic value productivity.

In addition, the research needs to be done to show the importance the growth hormone on the reproductive side, and to obtain a picture of polymorphism of reproductive hormone in calves from cattle with Limousin cattle. Research on genetic polymorphism of growth hormone (GH) gene has not been done in crossbred calves from Limousin cattle, so it is interesting to be investigated deeper so that the results obtained can be used as a reference for obtaining cattle breeds that have a good quality of performance and power reproduction.

Follicle Stimulating Hormone (FSH) is a glycoprotein hormone produced by the pituitary gland, which functions to regulate reproduction in mammals, both male and female (7). In females, it functions for the proliferation and development of follicles until ovulation (8). While in males, the combination of FSH and testosterone is a tropical hormone that regulates Sertoli cell function, which is necessary for initiation and maintenance of spermatozoa quality and quantity (9). FSH hormones consist of $\alpha$ and $\beta$ sub units. $\beta$-sub units play a role in determining the specificity of bonding with receptors (FSHR) (10). It has been reported that the presence of exon 3 mutations of the FSH $\beta$-sub-unit genes in bulls were identified to have lower fresh cement concentrations, a lower percentage of acrosome integrity on fresh and frozen cement, more low motility in frozen semen (11). Research on genetic polymorphism of growth hormone $(\mathrm{GH})$ and $\beta$-sub-unit genes has not been done in crossbred calves from Limousin cattle, so it is interesting to obtained can be used as a reference for obtaining a cattle breeds that have a good performance and power reproduction.

\section{Materials and methods}

\section{Research materials}

The main material of this research is DNA Genome which obtained from the blood of Madura's calves from Limousin cement artificial insemination with 14 blood samples. Genomic DNA was then extracted using a DNA 
Extraction QIAamp Mini spin column Kit (Thermo Fisher Scientific Inc. Invitrogen) to degrade the cell walls, proteins, and fats. The DNA samples were then ready for PCR reactions. The primer used to amplify GH gene (Table $1)$.

\section{Materials and equipments}

The main ingredient is DNA samples taken from the whole blood of Madura calves from Limousin cement artificial insemination from Bangkalan, Madura District with ten samples. Supporting materials include: Primer (GH gene Primer), HaeIII Restriction enzyme, PstI restriction enzyme, DNA Extraction Materials (K Proteinase, Absolute Ethanol, Lysis Buffer, A \& B Wash buffer), PCR materials (dNTP mix, Taq DNA polymerase enzyme), Electrophoresis Materials (Triss Base, boric acid, agarose, Na2 EDTA, Ethidium bromide, DNA Marker, DNA Loading dye), tissue and mica plastics.

\section{Collection of blood samples}

Madura cattles and Limousine cattle crossbred calves the sample $5 \mathrm{ml}$ of blood collected from jugular vein by using venojet and vacutainer tube with EDTA and then kept at $4^{\circ} \mathrm{C}$.

Table 1: The Primer Used to Amplify GH Gene

\begin{tabular}{llll}
\hline Name & Base Sequens Primer & Location & PCR Product (bp) \\
\hline F & 5'-AGAATCAGGCCCAGCAGAAATC-3' & Exon 3 and 4 & \\
$\mathrm{R}$ & 5'- GTCGTCACTGCGCATGTTTG-3' & & $329 \mathrm{bp}$ \\
\hline
\end{tabular}

\section{DNA extraction}

The DNA was isolated and purified using a QIAamp Mini spin column extraction DNA kit following the provided extraction protocol. A total of $200 \mu \mathrm{l}$ blood samples were lysed by adding $200 \mu 1$ lysis buffer solution and $20 \mu \mathrm{K}$ proteinase $(10 \mathrm{mg} / \mathrm{ml})$, the mixture was then incubated at $56^{\circ} \mathrm{C}$ for 60 minutes in the waterbath shaker. After incubation, the solution was then added $200 \mu \mathrm{l}$ absolute ethanol (96\%) and centrifuged $8000 \mathrm{x} \mathrm{g}$ for $1 \mathrm{~min}$.

DNA purification was done by spin column method with the addition of $500 \mu \mathrm{l}$ wash buffer I then continued with centrifugation at $8000 \mathrm{x} \mathrm{g}$ for 1 minute. After the supernatant was removed, the DNA was then washed again with $500 \mu \mathrm{l}$ wash buffer II and centrifuged at $14,000 \mathrm{x}$ g for $3 \mathrm{~min}$. After the supernatant was removed, the DNA was then dissolved in $200 \mu \mathrm{l}$ elution buffer and sterilized at $8000 \mathrm{x} g$ for further extraction of DNA to be stored and stored at $-20^{\circ} \mathrm{C}$.

\section{PCR-RFLP technique}

The PCR reaction composition was conditioned on 25 $\mu \mathrm{l}$ reaction volume comprising $100 \mathrm{ng}$ of DNA, $0.25 \mathrm{mM}$ each primer, $150 \mu \mathrm{M}$ dNTP, $2.5 \mathrm{mM} \mathrm{Mg} 2+, 0.5$ Taq DNA polymerase and $1 \mathrm{x}$ buffer. The condition of the PCR machine begins with the initial denaturation at $94^{\circ} \mathrm{C} \times 2$ minutes, followed by 35 subsequent cycles with each denaturation at $94^{\circ} \mathrm{C} \times 45$ seconds, with annealing temperature: $65^{\circ} \mathrm{C} \times 30 \mathrm{sec}(\mathrm{GH})$, followed by one end extension cycle at temperature $72^{\circ} \mathrm{C}$ for 5 minutes using GeneAmp PCR System 2400 Thermocycler (Perkin Elmer, Madison,Wisconsin, United States), for FSH $\beta$-sub unit primer with anealing at $60^{\circ} \mathrm{C}$. The PCR product was then electrophoresed on a $1.5 \%$ agarose gel with $1 \times$ TBE buffer (89 mM Tris, $89 \mathrm{mM}$ boric acid, $2 \mathrm{mM}$ Na2EDTA) containing $100 \mathrm{ng} / \mathrm{ml}$ ethidium bromide. Then visualized on UV transilluminator (gel documentation system). The allele is determined by interpreting the bands that are most migratory to the anode pole as allele 1 , allele 2 , and so on.

The PCR products obtained from each of the target genes were then analyzed using RFLP by cutting using restriction enzymes having cutting sites in the HaHII gene and the FSH $\beta$-PstI gene. A total of $4 \mu \mathrm{l}$ DNA PCR product added $0.5 \mu \mathrm{l}$, then incubated for 17 hours at $37^{\circ} \mathrm{C}$.

\section{Sequencing}

The determination of nucleotide sequences of $\mathrm{GH}$ (Growth Hormone) and rGH (receptor Growth Hormone) unit genes was done by DNA sequencing that is the final step to obtain data of nucleotide sequence from fragment result of PCR-RFLP propagation. The DNA bands that already restricted on an agarose gel as PCR-RFLP products serve as a mould in the sequencing reaction by using forward and reverse primers as in the time of amplification.

\section{Data analysis}

The diversity of individual genotypes can be determined from the DNA bands of the gene found. Each sample was compared to the same size (marker) and calculated the frequency of the allele. The frequency of alleles can be calculated using the Nei and Kumar formulas (12). Sequencing data analysis using UGENE 1.21.0 software. 
Table 2: Genotype and allele frequencies of Madrasin cattle. LL, LV, and VV = homozygot genotype, $\mathrm{L}$ and $\mathrm{V}=$ Allele

\begin{tabular}{lcccccc}
\hline \multirow{2}{*}{ Breed } & \multirow{2}{*}{$\mathrm{N}$} & \multicolumn{3}{c}{ Genotype Frequency } & \multicolumn{2}{c}{ Allele Frequency } \\
\cline { 3 - 7 } & & LL & LV & VV & L & V \\
\hline Madrasin & 14 & 0,928 & 0,017 & 0,00 & 0,96 & 0,075 \\
Madura & 10 & 1,00 & 0,00 & 0,00 & 1,00 & 0,00 \\
\hline
\end{tabular}

Table 3: Genotype and allele frequencies of Madrasin cattle. $\mathrm{AA}, \mathrm{AG}$ and $\mathrm{GG}=$ homozygot genotype, $\mathrm{A}$ and $\mathrm{G}=$ Allele

\begin{tabular}{lcccccc}
\hline \multirow{2}{*}{ Breed } & \multirow{2}{*}{$\mathrm{N}$} & \multicolumn{3}{c}{ Genotype Frequency } & \multicolumn{2}{c}{ Allele Frequency } \\
\cline { 3 - 7 } & & $\mathrm{AA}$ & $\mathrm{AG}$ & $\mathrm{GG}$ & $\mathrm{A}$ & $\mathrm{G}$ \\
\hline Madrasin & 14 & 0,857 & 0,142 & 0,000 & 0,925 & 0,075 \\
Limousin & 21 & 0,238 & 0,095 & 0,667 & 0,286 & 0,714 \\
\hline
\end{tabular}

\section{Resuts}

\section{The PCR result of GH gene}

PCR of 14 Madrasincattle's blood samples was performed to detect the presence of the Growth Hormone (GH) gene, the result of PCR showing 14 gene band GH using GH gene primers. Positive results are shown in Figure 1.

\section{$\begin{array}{lllllllllllllll}M & 1 & 2 & 3 & 4 & 5 & 6 & 7 & 8 & 9 & 10 & 11 & 12 & 13 & 14\end{array}$}

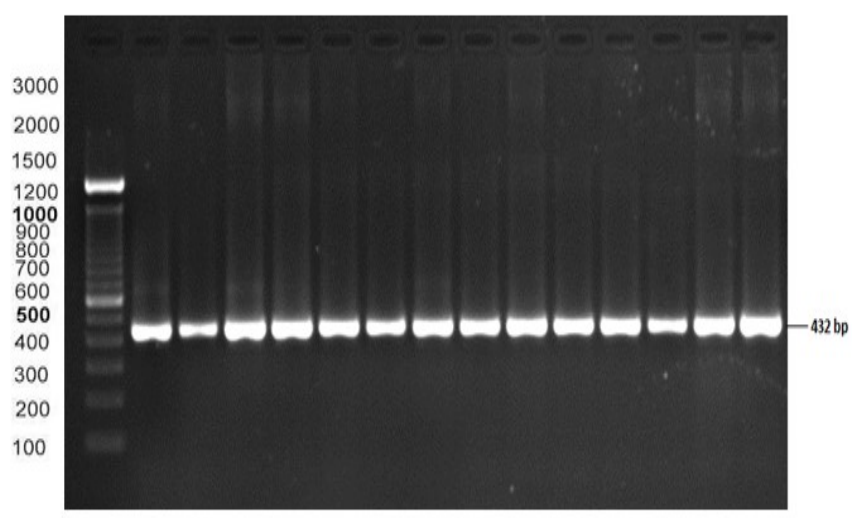

Figure 1: The PCR result of GH genes of Madrasin cattle. Lane M: Marker, Lanes 1-14 is the electrophoresis result of GH genes of Madrasin cattle with $432 \mathrm{bp}$.

\section{The PCR result of rGH gene}

The result of amplification of 14 Madrasin cattle in Bangkalan District conducted by PCR method resulted in 14 positive DNA samples using the rGH gene primers. The positive visualization results of electrophoresis can be seen in Figure 2.
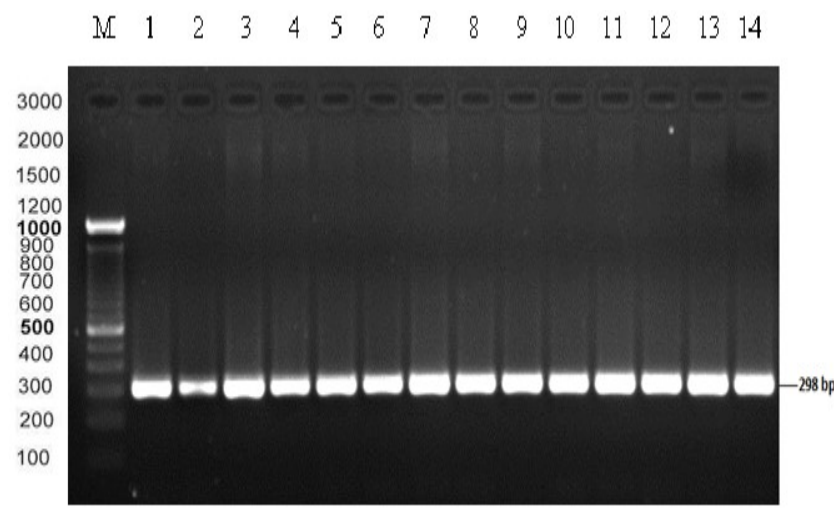

Figure 2: The electrophoresis result of PCR of Madrasin cattle's blood. $\mathrm{M}=$ DNA Marker. 1-14 = DNA Samples, lanes 1-14: PCR products (298 bp).

\section{The PCR-RFLP result of GH gene.}

After detecting the presence of the $\mathrm{GH}$ gene in Madrasin cattle using the PCR method, the RFLP or GH DNA gene cutting was performed using the AluI retrieval enzyme (5'-AG | CT-3'). Results of RFLP were $14 \mathrm{GH}$ gene samples divided into 4 bands, ie $(60 \mathrm{bp}, 100 \mathrm{bp}, 150$ $\mathrm{bp}$, and $300 \mathrm{bp}$ ). The result of RFLP of Madrasin cattle GH gene can be seen in Figure 3.

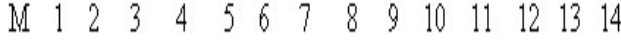

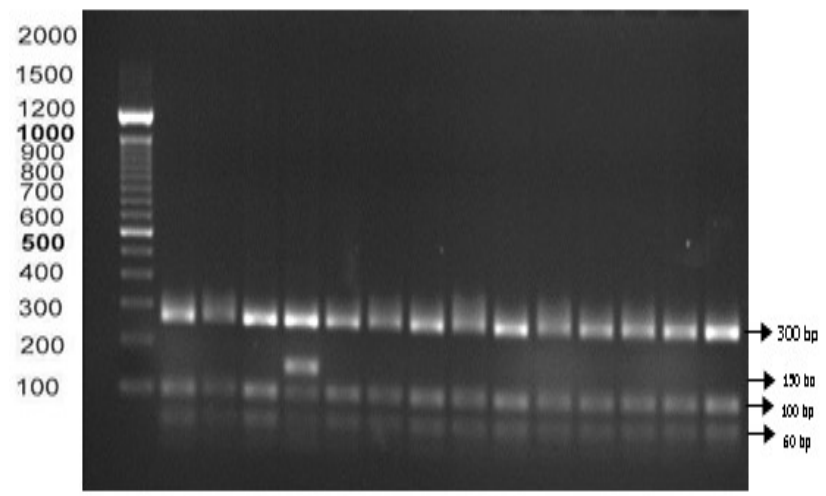

LL LL LL LV LL LL LL LLL LL LL LL LL LL

Figure 3: The electrophoresis result of PCR-RFLP using Alul restriction enzyme of Madrasin cattle's GH gene. Lane M: Marker, Lanes 1-3 and 5-14 LL genotype (60 bp, 100 bp, and $300 \mathrm{bp}$ ), Lane $4 \mathrm{LV}$ genotype (60 bp, $100 \mathrm{bp}, 150$ $\mathrm{bp}$, and $300 \mathrm{bp}$ ).

\section{The PCR-RFLP result of rGH gene}

The result of amplification test with PCR product obtained was then digested with AluI restriction enzyme, 
obtaining band yield of $167 \mathrm{bp}$ and $81 \mathrm{bp}$ in Madrasin cattle. The electrophoresis results in the process of PCRRFLP of Madrasin cattle's blood sample can be seen in Figure 4.

\section{$\begin{array}{lllllllllllllll}M & 1 & 2 & 3 & 4 & 5 & 6 & 7 & 8 & 9 & 10 & 11 & 12 & 13 & 14\end{array}$}

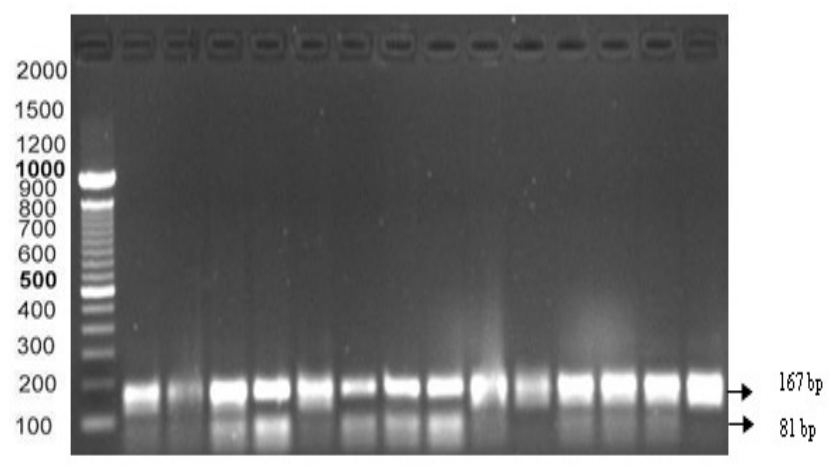

$\mathrm{AA} A \mathrm{AA} A \mathrm{AA} A \mathrm{AAAAG} A \mathrm{AAAA}$

Figure 4: The electrophoresis result of PCR-RFLP using AluI restriction enzyme of Madrasin cattle's rGH gene. M $=$ DNA Marker, AA and AG = Homozygot Genotype. 1-14 = DNA Samples, lanes 1-9 and 11-13 AA genotype (167 bp and $81 \mathrm{bp}$ ), lane 10 and 14 AG genotype (298 bp, $167 \mathrm{bp}$, $81 \mathrm{bp})$.

\section{Discusion}

\section{PCR of GH}

The PCR results of the Madrasin cattle's GH gene showed a $432 \mathrm{bp}$ band, this corresponds to the bands in the genome library GH itself is a hormone candidate that plays a role regulating milk production, carcass and immune system (13). The GH gene is one of the most important things in managing the properties of high-value livestock so that the GH gene who Marked Assisted Selection (MAS) program in cows. GH gene plays a role in regulating postpartum growth, tissue, muscle, bone, adipose tissue development, mammary gland growth, lactation, reproduction, metabolism of carbohydrate, protein, and body fat. The GH gene requires a receptor in its expression mechanism to a network mediated by the rGH gene or growth hormone receptor (14).

\section{PCR of rGH}

Based on the results of blood amplification by PCR method, continued with electrophoresis readings obtained positive sample results. The rGH genes found in all of Madrasin cattle's blood samples can be detected by PCR with a length of product amplified by the rGH gene segment of 298 bp located in exon 10. The results of this research are similar to those identified by the genetic diversity of $\mathrm{rGH}$ genes in Limousin cattle previously performed by Zulkarnaim (15).

The success rate of $\mathrm{rGH}$ gene amplification in this research was $100 \%$. The amplification results of the $\mathrm{rGH}$ gene segment were visualized on a $1.5 \%$ agarose gel presented (Figure 3.2). The temperature and duration of the annealing also determine the degree of amplification specificity and the cause of other factors that play a role in determining the success of amplification is the quality or purity of DNA used as template DNA.

\section{RFLP of GH}

Amplification of Madrasin cattle's GH gene using PCR method is known to have 432 bp length, which will be followed by cutting of Madrasin gene site using AluI restricition enzyme. Based on RFLP result, PCR product along $432 \mathrm{bp}$ produce 2 allele that is $\mathrm{L}$ and $\mathrm{V}$, whereas in Madura cattle can only be found 1 allele that is L allele.

Restrictive enzymes can recognize the GH gene at the cutting site, this is because the DNA sequence at the cutting site is not mutated. The triplet codon thus formed is CTG which encodes the Leusin allele (L) (16). L allele itself is shown with fragment length (60 bp, $100 \mathrm{bp}$, and $300 \mathrm{bp}$ ).

The diversity of the Madrasin cattle's GH gene is indicated by the presence of $\mathrm{V}$ allele resulting from the presence of a mutation or change of base causing the change of serine amino acid $(\mathrm{C})$ to glycine $(\mathrm{G})$ so that the Madrasin cattle's GH gene cutting phase changes from AGTC to AGGT. As a result of this change is formed codon triplet GTG that encode the valine amino acid (V) (17). V allele itself is shown with fragment length $60 \mathrm{bp}$, $100 \mathrm{bp}, 150 \mathrm{bp}$ and $300 \mathrm{bp}$.

\section{Genotype frequency and GH gene allele}

According to the Volkandri's research (18), the frequency of genotypes and the L allele of Madura cattle were 1.00 and 1.00 respectively. Whereas in Madrasin cattle got the frequency of genotype and allele respectively participate 0,928 and 0,96 . Based on these differences allegedly occurring changes in allele and genotype frequencies between Madura cattle with Madrasin cattle due to cross-breeding with Limousin cattle.

This is in accordance with Rachman's research (19), which found the genotype of Limousin cattle's frozen cement used in artificial insemination in Larangan subdistrict, Pamekasan District. Successively detected L and V alleles have frequencies of 0.67 and 0.33 and 0.82 and 0.18 respectively. This proves that Limousin cattle have a $\mathrm{V}$ allele that is not owned by Madura cattle.

\section{RFLP of rGH}

Based on the results of treatment using PRC-RFLP of the amplified rGH gene segment there are two AluI cutting 
sites known as allele A and allele G, allele A is marked by truncation of $298 \mathrm{bp}$ fragments into two parts along $167 \mathrm{bp}$ and $81 \mathrm{bp}$. The fragment of the rGH gene that has an AluI enzyme cutting site will indicate that no mutation occurs but if no cutting site is indicated in the absence of a cutting by the AluI enzyme, it can be stated that there is a mutation in the rGH fragment site.

The diversity in the AluI rGH gene segment is thought to be due to the mutation or alteration of the base causing the change of serine amino acids to glycine. The change causes the cutting site not to be recognized by the Alu1 enzyme, resulting in an 81 bp fragment known as the $G$ allele $(13,20)$. Results of genotyping on Madrasin cattle's segment of the rGH gene resulted in two fragments that were cut off, ie AAgenotype, which showed fragments along $81 \mathrm{bp}$ and $167 \mathrm{bp}$ and fragments that were cut into one band called AG genotype which showed fragment along $81 \mathrm{bp}$ at (Figure 3.4).

The results of this research differ from the results of previous research conducted by Zulkarnaim (15), that is cutting the fragment of rGH gene in Limousin cattle yield three genotypes namely AA, GG, AG, AA genotype is shown as fragments along $167 \mathrm{bp}, 81 \mathrm{bp}$ and $50 \mathrm{bp}$, and genotype AG is shown as fragments along $167 \mathrm{bp}, 131 \mathrm{bp}$, $81 \mathrm{bp}$ and $50 \mathrm{bp}$.

\section{Frequency of genotype and rGH gene allele}

The result of the analysis of the rGH aluI gene segment showed that the frequency of the allele A was $86 \%$ higher than the frequency of the allele $\mathrm{G}$, the $\mathrm{A}$ and $\mathrm{G}$ allele frequencies in Madrasin cattle were 0.92 and 0.08 , respectively (Table 3 ), while the AA and AG genotype were 0.85 and 0.14 . The results of this research differed greatly from previous results of Limousin cattle which had $\mathrm{A}$ and $\mathrm{G}$ frequency in Limousin cattle respectively of 0.286 and 0.174 , while AA and AG genotype were 0.238 and 0.095. That Madrasin cattle have different Alel and Genotype with Limousin cattle.

In conclusion, the $\mathrm{GH}$ and rGH undergo changes on polymorphisms in Madrasin cattle and this research information can be used in selection.

\section{Acknowledgement}

The study was supported by funding from the Directorate General of Higher Education (DIKTI) 2016. The National Education Ministry. Republic of Indonesia.

\section{References}

1. Rouse JE. Cattle of Africa and Asia. Oklahoma: University of Oklahoma Press. 1972.

2. Payne WJA, Wilson. An Introduction to Animal Husbandry in the Tropics. Oxford: Blackwell Science Ltd. 1999.

3. Soehadji. Kebijakan Pengembangan Ternak Potong di Indonesia Tinjauan Khusus Sapi Madura. Pros. Pertemuan Ilmiah Hasil Penelitian dan Pengembangan Sapi Madura. Sumenep. 1993;p.1-12.

4. Hetzel DJS. Construction of A bovine gene map. Proceedings of the New Zealand Soc Ani Prod. 1989;49:53-56.

5. Mitra A, Schlee P, Balakrishnan CR, Pirchner F. Polymorphisme at growth hormone and prolactine loci in Indiancattle and buffalo. J Ani Breed Gene. 1995;112:71-74.

6. Hoj S, Fredholm M, Nielsen VH. Growth hormonegene polymorphism associated with selection for milk fatproduction in lines of cattle. Ani Gen. 1993;24:91-96.

7. Ulloa-Aguirre A, Midgley AR, Beitinsand IZ, Padmanabhan V. Follicle-stimulating hormones: characterization andphysiological relevance. Endocrinol. 1995;Rev.16:765-787.

8. McGee EA, Hsueh AJ. Initial andcyclic recruitment of ovarian follicles. Endocrinol. 2000;Rev.21:200-214

9. Ohta T, Miyake H, Miura C, Kamei H, Aidaand K, Miura T. Folliclestimulating hormone induces spermatogenesis mediatedby androgen production in Japanese eel,Anguilla japonica. Biol Reprod. 2007;77: 970-977

10. Fan QR, Hendrickson WA. Structure of human follicle-stimulating hormone incomplex with its receptor. Nature. 2005;433:269-277.

11. Dai L, Zhao Z, Zhao R, Xiao S, Jiang H, Yue X, Li X, Gao Y, Liu J, Zhang J. Effects of novel single nucleotidepolymorphisms of the FSH beta-subunitgene on semen quality and fertility in bulls. Anim Rep Sci. 2009;114:14-22.

12. Nei M, Kumar S. Molecular Evolution and Physologenetics. Oxford University Press, New York. 2000.

13. Ge W, ME Davis, HC Hines, KM Irvin, RCM Simmen. Association of single nucleotide polymorphisms in the growth hormone and growth hormone receptor genes with blood serum insulin-like growth factor I concentration and growth traits in Angus cattle. J Anim Sci. 2003;81:641-648.

14. Akers RM. Major advances associated with hormone and growth factor regulation of mammary growth and lavtation in dairy cow. $\mathrm{J}$ Dairy Sci. 2006;89:1222-1234.

15. Zulkarnaim, Jakaria, Noor RR. Identifikasi keragaman genetik gen reseptor. Hormone pertumbuhan (GHR Alu1) pada sapi Bali. Med Peternakan. 2010;33:81-87.

16. Woychick RP, Camper SA, Lyons RH, Horowitz S, Goodwin EC, Rottman FM. Cloning and nucleotide sequencing of the bovine growth hormone gene. Nucleic Acids Res. 1982;10(22):7197- 7210.

17. Zhang HM, Brown DR, Denise SK, Ax RL Polymerase Chain Reaction Restriction Fragment Length Polymorphism Analyzes of The Bovine Somatropin Gene. J Ani Sci. 1993;(71):2276.

18. Volkandri SD, Hartatik T, Sumadi. Polimorfisme Gen Growth Hormone pada sapi Limura. Fakultas Peternakan, Universitas Gadjah Mada Buletin Peternakan. 2013;37(2):67-73.

19. Rachman MP. Polimorfisme gen Growth Hormone (GH) pada sapi Madura danPersilangan Limousin-Madura. Tesis.Program Studi Bioteknologi, Jurusan Antar Bidang, Program Pascasarjana, Universitas Gadjah Mada.Yogyakarta. 2011.

20. Di Stasio L, Destefanis G, Brugiapaglia A, Albera A, Rolando A. Polymorphism of the GHR gene in cattle and relationship with meat production and quality. Anim Genet. 2005;36:138-140. 